\title{
PRODUCT INNOVATION IN UK MANUFACTURING COMPANIES
}

\author{
Keith Goffin, Marek Szwejczewski, Michael Sweeney and Colin New \\ Cranfield School of Management, \\ Cranfield, Bedfordshire MK43 0AL, \\ England, UK
}

\section{BIOGRAPHICAL NOTES}

Keith Goffin graduated from Durham University in 1977 with a first class honours degree in Physics and subsequently obtained a masters in Medical Physics from Aberdeen University. In 1980 he joined the Medical Products Group of Hewlett-Packard (HP) in Germany as an engineer working on new product development. Later, he held various management roles including Product Marketing Manager with responsibility for the product which has now become the world's most successful patient monitor. Parallel to his work at HP, Keith studied for a $\mathrm{PhD}$, completing his thesis in record time. He joined the faculty of Cranfield School of Management 1995 and his research interests are product innovation and supplier management. In addition he has acted as a consultant on innovation to a number of wellknown companies including Rank-Xerox, Monsanto, Kellogg's and ICL.

Marek Szwejczewski is a Senior Research Fellow and is responsible for the administration and judging of the Management Today/Cranfield School of Management Best Factory Awards. His first degree is in Economics and he received a Master of Science degree in Computer Integrated Manufacturing from Cranfield University in 1991. Prior to joining Cranfield as a researcher he worked as a marketing manager in several industry sectors ranging from retailing to telecommunications. His current research interests are manufacturing strategy, performance measurement and world class manufacturing and he has published in a number of journals including The TQM Magazine, the International Journal of Physical Distribution and Logistics Management and the International Journal of Operations and Production Management.

Colin New is Professor of Manufacturing Strategy and Deputy Director of Cranfield School of Management. He started his industrial career with Rolls-Royce Aero Engines in Derby, where he was involved in advanced production planning and control systems. He subsequently completed the Masters programme at London Business School with Distinction and then stayed on to teach for seven years before moving to Cranfield in 1978. His research areas include manufacturing strategy, manufacturing planning and control, and distribution systems. A number of manufacturing companies across Europe and the United States management regularly use Colin as a consultant on manufacturing strategy. Colin is the author of three books and a large number of papers and articles. He directs the Management Today UK Best Factory Awards scheme and is chairman of the judging panel. 


\title{
PRODUCT INNOVATION IN UK MANUFACTURING COMPANIES
}

\section{Authors \\ Institute}

\begin{abstract}
In many sectors of manufacturing industry, product innovation is an important way for companies to achieve competitive advantage. Regular introductions of new products can be essential, especially in fast-moving markets. But how often do companies introduce new products? A database of UK manufacturing plants was analysed to determine the innovation rates and typical product development times in specific industry sectors. The results show a wide spread in the development times and innovation rates even within closely defined sectors-this implies that some companies are particularly efficient at product innovation whereas others need to improve in this area. In addition, the research identifies a number of key areas of innovation which require further investigation, both within the UK and on an international basis.
\end{abstract}

\section{KEYWORDS}

Product innovation, new product development, cycle times, UK manufacturing

\section{ACKNOWLEDGEMENT}

The authors gratefully acknowledge the support of the Anglo-German Foundation, who funded the research described in this paper.

\section{INTRODUCTION}


The speed and the frequency with which new products can be developed are fundamental issues and consequently they have become a focus for management attention over the last few years. Reflecting the importance of the business issues involved, there has been a substantial stream of research investigating the topic faster and more frequent product innovation. However, many questions remain to be answered. For instance, how often do companies typically introduce new products? How long does it typically take them? And, are there major differences between different industries? These were the background questions which initiated the exploratory research on product innovation described in this paper.

Without frequent new products, companies can quickly lose competitiveness and market share_- "if you do not innovate, old products will be overtaken by new technology" [1]. A recent survey of European manufacturing managers identified that the ability to introduce new products was one of the key challenges now facing European companies [2]. Companies that have recognised this are responding; many are talking about the importance of innovation and several have launched major innovation initiatives. For example, an executive from the German company Siemens recently stated, "Any intelligent corporate strategy must have innovation at its very heart" [3]. Other companies which are also launching projects to promote more innovation include Renault, Philips, Ericson, BT and BASF [4]; and 3M [5]. Innovation is a topical management issue: as one executive from $3 \mathrm{M}$ has said "today, the idea of innovation is widely accepted... in 1994 and 1995, around 275 [management] books published in the United States had the word innovation in their titles"[6].

The time required to develop and introduce a new product—variously referred to as time-to-market or cycle time-is a key performance measure which is often 
targeted by companies for improvement. This is because "time to market is widely viewed as a key source of competitive advantage, particularly in fast-cycle industries" [7]. Increased competition is forcing companies to concentrate on developing and successfully introducing new products faster [8]. The importance of reducing cycle time has been highly stressed: "in the highly competitive environment of the nineties, time to market with new products can make or break companies" [9].

This article considers both cycle time and the rate of new product introductions - as an indication of innovation - in British manufacturing industry. Although fast new product development is recognised as crucial, comparatively little data has been published which identifies the typical cycle times in various industries. This information is potentially valuable, as it would give companies a benchmark; a comparison against which they can measure their own performance. Similarly, data on the numbers of new products introduced over time by companies in different sectors is limited. To address this gap, this study measures cycle times and innovation rates. The aims of the research were:

1) To investigate cycle times and innovation rates of companies in various sectors of UK manufacturing industry and determine whether there is a large amount of variation within an industrial sector.

2) To investigate whether product complexity affects cycle time within a sector.

\section{INNOVATION AND NEW PRODUCT DEVELOPMENT}

\section{Innovation: Its Importance, Management and Measurement}

"Innovation is the principal engine of economic growth" [10]. New products are the fundamental part of innovation in manufacturing industry and are a key source of competitive advantage [11]. As competition increases in many markets, companies 
must relentlessly develop innovative new products if they are to be successful [4]. Recognising this, many companies are attempting to introduce more new products, however, the success rate for new products is considered by observers to be very low [12].

Managing innovation may prove difficult and the question has even been asked "to what extent can product innovation be planned?" [13]. A key problem is the wide range of factors which influence the success or failure of new products, including the allocation of resources, the skill of key staff, the generation of ideas and the organisation of development teams (ibid). Gobeli and Brown [14] identified the typical problems that companies face with managing product innovation. Problems exist at every stage of product innovation; from the creation of ideas, to the choice of the best ideas, to product development, to the introduction of products onto the market. Therefore, companies face a difficult task in trying to stimulate more efficient innovation.

One widely publicised approach by the $3 \mathrm{M}$ company has been the use of strict financial measures to highlight the importance of product innovation and stimulate the development of more new products. One goal used by $3 \mathrm{M}$ is that $30 \%$ of revenues must be generated by products less than four years old [15]. However, managing innovation is difficult because it is not necessarily a logical process [16], and despite the constant stream of publications on innovation, it is far from clear how companies can best become more innovative. It is certainly not as clear cut as one author who claimed; "there is no doubt that properly managed innovation can bring industry the solutions which it needs and help it to achieve a competitive edge" [17].

Data on companies' innovation rates is rarely published. Although companies such as Hewlett-Packard and $3 \mathrm{M}$ publish the amount of revenue which has been 
generated by new products in their annual reports, few other direct indications are available. Rare data on innovation rates can be found in economic research by Acs [11], who measured the innovations related to million employees in an industry and found that small companies are more innovative than large ones. In addition, "there are considerable differences in innovation rates across industries" (ibid). However, it should be noted that this investigation concentrated on the industry level and used data from 1982, as more recent data was not available.

Economists have long studied innovation because of the links to economic growth. However, they have normally studied it at a macro-level and this has acknowledged limitations; "when we look at technological change in the aggregate... we are obviously forced to simplify an enormously complicated set of activities" [18]. In addition, measuring innovative activity is difficult as has been pointed out by Geroski [19] who stated: "studies of the causes and consequences of innovative activity have often been stymied by the difficulty of measuring 'innovation"'. Various measures of innovation have been used by economists such as $R \& D$ expenditures, or the number of major innovations generated in an industry over time but innovation at the product level has been largely ignored.

It appears that previous researchers have not looked in detail at innovation rates-measured as the percentage of product portfolios that are renewed per year-at individual companies within an industry and so this topic was chosen as for investigation.

\section{The Importance of Fast New Product Development}

Much has been published on the need for companies to develop new products faster than their competitors. It is becoming increasingly important for companies to focus 
on reducing cycle time [7]. Fast new product development (NPD) is one of the key themes of Time Based Competition, which was largely promoted through the work of Stalk [20] and has been a key focus in manufacturing industry since the end of the 1980s.

Fast cycle time is given credit in the business press with two main advantages. If the product which is introduced is a totally new concept, then being first-to-market enables a company to define key market requirements and establish itself before competitors enter the market. In established markets, introducing new products faster gives real competitive advantage, because products which reach the market sooner are credited with increased profit and market share [20]. One example of the advantages of faster NPD are figures from printer development projects at the Hewlett-Packard Company [21]. These show that high-technology products which come out six months late will earn $33 \%$ less profit over a five-year period. These figures have been widely quoted as evidence that faster cycle time leads to higher profits, without any real consideration of their (doubtful) external validity. It can be stated that, although the advantages of short cycle times appear clear in the business literature, they are not backed by clear, unequivocal evidence.

For instance, in a comprehensive study of the chemicals industry, Cooper and Kleinschmidt [22] found that the link between fast cycle time and profitability was weak. Similarly, Ellis and Curtis [23] showed that fast R\&D in isolation does not lead to effective innovation. Faster NPD does not appear empirically to be directly correlated to higher sales either [24] and "it is futile to expect large profit gains from shortening cycle time" [23]. In fact it appears that cycle time reductions should only be pursued if the technical and organisational foundations of NPD are improved at the same time [25]. However, other researchers found that faster cycle time (measured at 
the volume production stage) did affect market share positively, provided the lead over competitors was above a minimum threshold level [7].

\section{Techniques for Faster NPD?}

After faster NPD became recognised at the end of the 1980s as a pertinent goal for companies, there followed a wave of prescriptive articles on the ways in which it could be achieved (see, for example; [26],[27],[28]). Many of these were based on anecdotal evidence from specific development projects which have questionable external validity. The widespread acceptance of anecdotal evidence allowed claims to be made that certain techniques would reduce cycle time significantly. Unfortunately, "most prescriptions for cycle time reduction are based on little hard evidence" [29].

For example, one technique which was hailed as a major advance in reducing cycle time was Quality Function Deployment (QFD)—a Japanese method for ensuring that customer requirements are accurately captured. Griffin [30] has clearly shown this belief to be flawed. Another technique which has been prescribed as the way to accelerate new product development is concurrent engineering (CE), in which all functional areas commence work on NPD simultaneously. However, CE can be difficult to apply ([31],[32]), and may involve some trade-offs [33]. Another study showed "no significant relationship was found between the use of concurrent engineering and financial performance" [23].

Faster NPD cannot be achieved simply by applying specific techniques.

\section{Broader}

organisational aspects also need to be considered ([24],[34],[35],[36]). In addition the skills and motivation of the people working on innovation is crucial [37], as is their commitment to fast cycle time [38]. It is important not only to accelerate NPD; 
Cooper [39] has noted that choosing the right projects from the start and managing them appropriately is key [40].

In conclusion, it can be said that there is a wide range of techniques for faster NPD but that the use of any of these will not, in itself, guarantee reduced cycle times. Bringing products to market faster is just not that simple- the situation and the way techniques are implemented plays a key role ([41],[42]).

\section{New Product Development Measures}

Which measures are necessary to the understanding of NPD? Griffin [43], identified that a fundamental problem of research into techniques which reduce cycle times was "there were no baseline measures from which to form comparisons" and demonstrated the importance of establishing accurate and comprehensive NPD metrics. Ellis and Curtis [23], showed that few companies capture accurately the time from idea to market and this type of measurement is essential because, without it, valid comparisons are impossible.

Griffin's work recommends that metrics for NPD should be comprehensive and cover the characteristics of the project (inputs); the process of NPD itself; and the outcomes [43]. One of the metrics, cycle time, was identified as particularly prone to measurement error-because companies measure development times differently and often do not keep accurate records of the starting dates of projects. An approach is recommended which counteracts these problems. However, a limitation of this approach is that it requires extensive interviewing of managers to accurately determine all of the NPD metrics and this has limited the application of the ideas, to-date, to a sample to 21 divisions from 11 companies (across five industries). Griffin has also 
analysed the relationships between cycle times, product complexity and other factors [44].

The majority of cycle times which have been published stem from individual projects and (probably) suffer from measurement accuracy problems. Griffin ([44] summarises previously published cycle times from 21 companies and then gives empirical data summarising 343 projects at eleven companies. Toepfer [26] lists 8 cycle times (four of which are from the same sources as [44]). Another estimate of cycle times comes from a survey (189 companies in the Product Development and Management Association) from which Page [45] concluded that "it takes the average company 2.95 years to develop more innovative types of new products" and "over a recent five-year period, the companies introduced an average of 37.5 new products, whereas the median was twelve". A survey by the consultants Pittliglio Rabin Todd \& McGrath (PRTM) [46] showed that automotive and industrial companies were setting themselves the goal of reducing cycle times by $14 \%$, whereas electronics companies were aiming for a $23 \%$ reduction. However, the published version of this survey failed to identify the actual values of the cycle time in different sectors.

It can be seen that published data on cycle times is sparse and some of it is possibly unreliable. As Griffin concluded; “one unexplored research issue is how long product development actually takes" [44].

\section{RESEARCH DESIGN}

The principal aim of this research was to obtain values for innovation rates and NPD cycle times from a wide range of companies across different industrial sectors. Consequently, it was decided to include new product development and innovation as part of a wider, ongoing investigation of the performance of UK manufacturing 
industry. A research programme was initiated in 1992, based on a highly-publicised annual competition to identify and reward excellence in UK manufacturing industrythe Best Factory Awards (BFA).

The BFA programme is run by Management Today (a leading UK monthly management magazine) and Cranfield School of Management. The programme recognises manufacturing excellence and collects detailed information from industry for research and bench-marking purposes. The annual awards are open to any manufacturer with a UK-based plant which completes a detailed 14 page, confidential questionnaire covering performance data (e.g. delivery reliability), the products produced, management policies, etc. Questionnaires are analysed and this results in a short-list of manufacturing plants which have high performance relative to the "norms" of their industry. A panel of judges visits short-listed companies, verifies the performance data, probes managers on their manufacturing strategy and checks issues such as the active participation of employees in quality management. Each year seven categories of prizes are awarded; the selection process itself has been described elsewhere in more detail [47].

A key point to note about the BFA programme is that, over the last five years, over 1200 companies have entered the competition and so the questionnaire is welltested. In addition, the quality of the data is believed to be very high—entrants know that they may receive a visit where the values they give in their answers will be checked. Therefore, there is strong indirect pressure to answer accurately and honestly. In addition since the programme was initiated, the judges have visited 74 plants (6\% of the total) and verified data integrity for these plants. The BFA database has previously been used for a number of empirical studies, which typically have combined analysis of the data with in-depth case studies of companies from the 
database. Examples include an investigation of factory performance [47] and new data on supplier management [48].

One of the sections of the BFA questionnaire looks directly at innovationcollecting information on NPD cycle time, plus current and (estimated) future innovation. The relevant questions from the BFA questionnaire are given in the Appendix. In designing the overall questionnaire, an appropriate compromise had to be made between the number and depth of questions being asked and the maximum time that respondents' companies are willing to invest to answer the questions. The result is a detailed questionnaire which captures comprehensive performance data but which requires significant resources and effort to be invested on the part of respondent companies. Many companies comment that much of the data required is not readily available within their companies (but that completing the questionnaire is a positive, if time consuming, learning experience for management). As the questionnaire was already long, the scope of the questions on innovation and NPD which could realistically be asked was limited and a strong focus was required. This led to the inclusion of three questions, which capture the following values:

- Cycle time (defined as "from start of detail design to market launch")

- The number of new products launched over the last five years (and the number of these which were product line extensions and which were totally new)

- The number of new products expected to be launched in the next five years

Each of the questions was carefully designed and extensively piloted before being included. As an introduction to the questions, text explains what is meant by significantly new products (refer to the Appendix).

The remainder of the questionnaire covers a wide range of manufacturing performance measures, from lead-times to inventory profile. Background information 
on products allows companies to be classified by Standard Industry Codes (SIC). The emphasis throughout the questionnaire is on collecting objective and unambiguous data. Several questions provide useful points on which to compare the data on innovation. These are the number of products manufactured by a plant (can be used to estimate the innovation rate, using the data on the number of product launches) and the product complexity.

\section{RESULTS AND DISCUSSION}

A total of 649 plants entered the BFA programme between 1993 and 1995, coming from a wide range of industries including the electronics, engineering, process and household products sectors. A range of plant sizes was represented; 163 (25\%) manufacturing plants were small businesses and employed less than 500 employees. Ownership of the plants was as follows: UK owned (42\%); UK owned small businesses (22\%); UK joint owned (5\%); US owned (14\%); Japanese owned (2\%); European owned (10\%); and (other) foreign owned (5\%). Although the sample cannot be claimed to be fully representative of UK manufacturing industry, because the companies are self-selecting, the quantity, quality and depth of data means that the database is still an important research tool.

It would have been possible to calculate mean cycle times and innovation rates across the whole sample, similar to the approach taken by Page [45]. However, it was felt that this approach would be wrong-it would compare values across very different sectors and the resulting average values would be of little value. Therefore, the sample for the actual analysis was focused on five closely defined sectors where sufficient data existed for meaningful comparisons (i.e. sectors in which there were more than 25). The five sectors where sufficient data was available were the Intermediate and 
General Engineering; Electronics; Electronic Components; Chemicals and Food, Drink and Tobacco. These five sectors contained data from a total of 340 companies. (Due to missing data, certain tables contain less than this number of data points.)

\section{Cycle Time}

Table 1 shows the results of the analysis of the cycle times for the sample companies, by industrial sector. It can be seen that the mean cycle time in the Intermediate and General Engineering sector is 16 months, for Electronics 16.8 months, etc. Analysis of variance was used to test whether the differences between cycle times in different sectors are significant. This analysis showed that only the Food, Drinks and Tobacco sector has cycle times that are significantly different from the other four sectors $(\mathrm{F}$ ratio $=6.1780 ; \mathrm{F}$ probability $=.0001)$

Of particular interest are the large standard deviations, for instance, 10.7 months for engineering. Large standard deviations are seen in all five sectors, indicating a large spread of cycle times within sectors. This is an interesting result as it illustrates the danger of quoting only average values for a sector (i.e. the approach taken by Page [45] is probably best avoided). There are several possible explanations for the wide range of values. One is that the companies within any particular sector develop products of significantly different complexity (and this leads to different cycle times). This possibility was investigated by analysing the cycle time data versus the product complexity.

Insert Table 1

\section{Cycle Time versus Product Complexity}


It would seem intuitively clear that more complex products would take longer to develop. Therefore, a check was made to see if there was any correlation between the cycle time and product complexity. Defining product complexity is difficult-there is not a simple proxy measure for it. Griffin [44] used the number of product features but this approach could lead to problems of interpretation, especially within a survey format. Therefore, as a measure of complexity, the number of different components, purchased items or assemblies in the product with the largest output (at manufacturing cost) was taken; this was termed the "product part complexity".

Table 2 shows the results of an analysis on the effect of product complexity on cycle time in each sector. It can be seen that the correlations are weak and not significant. Therefore, the differences in cycle times are not simply explained by differences in product parts complexity. More investigation is needed to establish the reasons for the widely varying cycle times within sectors.

\section{Insert Table 2}

\section{Innovation Rates by Sector}

Innovation rate was operationalised by taking the number of new products introduced over the previous five years, expressed as a percentage of the total product range. Therefore, from Table 3 it can be seen that the median innovation rate for engineering was $1.8 \%$ but the top quartile of engineering companies had an innovation rate of 9.6\%. It is interesting to note from Table 3 that the innovation rates for the top quartiles of companies in any of the five sectors are much higher than the median values. This indicates that some companies appear to be much more effective at introducing new products than other companies in the same sector; this indicates that 
"best practices" may play a role. (Note that the survey did not attempt to measure the success of new products.)

Insert Table 3

\section{CONCLUSIONS}

The research gave a rare insight into the cycle times and innovation rates at a relatively large number of companies in five sectors of UK manufacturing industry. The results were interesting because, despite being obtained from narrowly defined sectors, they exhibited surprisingly large variations, in both cycle times and innovation rates. This suggests significant differences in innovation performance between companies operating in very similar markets and shows that average values for innovation measures should be used with caution.

The weak correlations between product complexity and cycle time may indicate that some companies are efficient at developing complex products faster than their competitors. However, as the proxy measure for complexity had its limitations, more investigation is needed before a conclusion can be reached on this.

The survey approach used in this investigation was exploratory and had some limitations. Firstly, only a few questions could be asked and, secondly, the questions may not have been, for some respondents, totally unambiguous. However, it collected data points from more companies than has previously been the case. The next stage of the research will need to look closer at the reasons behind the differences in innovation performance. The unit of analysis for this investigation will need to be the individual plant. As part of the BFA programme, the researchers can normally obtain access to respondent companies for in-depth further investigations and therefore the 
opportunity exists to study the companies in a sector or sectors further. The areas on which this type of research needs to focus are:

- Collecting further empirical data on cycle times and innovation rates in companies in different sectors. Verifying the survey data through follow-up interviews.

- Investigating the relationship between high innovation rates and market performance. Are the companies which regularly introduce new products achieving market growth and higher profit levels?

- How is innovation managed at the companies which develop new products faster? Can best practices be identified and how do these compare to the techniques for faster NPD that have received wide acclaim in the business press?

- Developing an appropriate methodology to accurately investigate the way companies manage their product innovation.

Just as innovation is a challenge for managers in industry, it offers many key challenges to management researchers-particularly in trying to identify best practices which have wider relevance and apply not only in the context of one project.

\section{ACKNOWLEDGEMENT}

The authors gratefully acknowledge the support of the Anglo-German Foundation who are funding a project investigating innovation management at manufacturing companies in Germany and the UK. The research described in this paper forms the first part of this project. 


\section{APPENDIX}

Section $\mathrm{F}$ of the Best Factory Awards questionnaire includes the questions on innovation and product development given below.

\section{F: PRODUCT INNOVATION}

A significantly new product is one which the plant has not made previously and which represents more than a simple change of material, colour or design variant. For example, in garment manufacturing a pair of trousers made in a new material for the new season would not be regarded as significant. However, if the trouser manufacturer started making overcoats this would be regarded as significant for the plant.

F1 How long does it typically take to bring a significant product innovation to market (from start of detail design to market launch)?

F2. (a) How many significantly new products (not including material or minor model changes) have you launched in the last five years?

F2.(b) Of these new products how many would you regard as:

\begin{tabular}{|l|l|}
\hline Extensions to existing product range(s) & \\
\hline Totally new (to plant) product range(s) & \\
\hline Other (please specify & \\
\hline
\end{tabular}

F2.(c) How many significantly new products (not including material or minor model changes)

do you expect to launch in the next five years?

F3 For those products made to a unique customer specific design What is the typical level of (please circle one of the numbers on the scale for each item):

\begin{tabular}{|l|lllll|}
\hline & Low & & & High \\
\hline Technological novelty & 1 & 2 & 3 & 4 & 5 \\
\hline Specific Applications Engineering & 1 & 2 & 3 & 4 & 5 \\
\hline Number of drawing changes required & 1 & 2 & 3 & 4 & 5 \\
\hline Use of new materials & 1 & 2 & 3 & 4 & 5 \\
\hline
\end{tabular}




\section{REFERENCES}

1. Gourlay, R. Innovation Roulette - How do you Launch a New Product while ensuring the Old Model keeps earning. Financial Times, 23rd January, 1996, p147

2. De Meyer, A. and Pycke, B. Falling Behind in Innovation: The 1996 Report on the European Manufacturing Futures Survey. INSEAD Working Paper Series, No. 96/95/TM, 1996.

3. Houlder, V. Management: Innovation under the Spotlight. Financial Times, 22nd January 1996, p131.

4. Houlder, V. Technology: Quiet Revolution. Financial Times, 26th March 1996, p143.

5. Anonymous. Face Value: The Mass Production of Ideas, and Other Possibilities. The Economist, Vol. 334, No. 7906, 18th March 1995, p111.

6. Coyne, W.E. Building a Tradition of Innovation. Transcript of The UK Innovation Lecture, 5th March 1996, Department of Trade and Industry URN 96/619.

7. Datar, S., Jordan, C.C., Kekre, S., Rajiv, S. and Srinivasan, K. Advantages of TimeBased New Product Development in a Fast-Cycle Industry. Journal of Marketing Research, Vol. XXXIV, No. 1, February 1997, pp36-49.

8. Cordero, R. Managing for Speed To Avoid Product Obsolescence: A Survey of Techniques. Journal of Product Innovation Management, Vol. 8, No. 4, December 1991, pp283-294.

9. Choperena, A.M. Fast Cycle Time - Driver of Innovation and Quality. Research Technology Management, Vol. 39, No. 3, May-June 1996, pp36-40.

10. Anonymous. The Machinery of Growth. The Economist, 11th January 1992, pp2123.

11. Acs, Z.J. Where New Things Come From. Inc. (USA), Vol. 16, No. 5, May 1994, p29.

12. Wind, Y. and Mahajan, V. New Product Development Process: A Perspective for Reexamination. Journal of Product Innovation Management ,Vol. 5, No. 4, December 1988, pp304-310.

13. Johne, F.A. and Snelson, P.A. Success Factors in Product Innovation: Selective Review of the Literature. Journal of Product Innovation Management ,Vol. 5, No. 2, June 1988, pp114-128.

14. Gobelli, D.H. and Brown, D.J. Improving the Process of Product Innovation. Research Technology Management, Vol. 36, No. 2, 1993, pp38-44.

15. Anonymous. Unthinking Shrinking. The Economist, Vol. 337, No. 7941, 9th September, 1995, p46.

16. Nonaka, I. and Kenney, M. Towards a New Theory of Innovation Management. European Management Review, Summer 1995, pp2-9.

17. Watson, P. It's Innovation, Stupid - Britain must Learn to Manage Better the Exploitation of its Inventions. Financial Times, 22nd March 1996, p101.

18. Rosegger, G. The Economics of Production and Innovation. Butterworth Heinemann, Oxford, 3rd Edition, 1996.

19. Geroski, P. Market Structure, Corporate Performance, and Innovative Activity. Clarendon Press, Oxford, 1994.

20. Stalk, G. Jr. Time - The Next Source of Competitive Advantage. Harvard Business Review, July/August 1988, pp41-51.

21. Dumaine, B. How Managers Succeed through Speed. Fortune, February 13th 1989, pp53-59.

22. Cooper, R.G. and Kleinschmidt, E.J. Major New Products: What Distinguishes the 
Winners in the Chemical Industry? Journal of Product Innovation Management, Vol. 10, No. 2, March

1993, pp90-111.

23. Ellis, L.E. and Curtis, C.C. Speedy R\&D: How Beneficial? Research Technology Management, Vol. 38, No. 4, July-August 1995, pp42-51.

24. Ittner, C.D. and Larcker, D.F. Product Development Cycle Time and Organizational Performance. Journal of Marketing Research, Vol. XXXIV, No. 1, February 1997, pp13-23.

25. Meyer, M.H. and Utterback, J. Product Development Cycle Time and Commercial Success. IEEE Trans. on Engineering Management, Vol. 42, No. 4, November 1995, pp297-304.

26. Toepfer, A. New Products - Cutting the Time to Market. Long Range Planning, Vol. 28, No. 2, 1995, pp61-78.

27. Millson, M.R., Raj, S.P. and Wilemon, D.W. A Survey of Major Approaches for Accelerating New Product Development. Journal of Product Innovation Management, Vol. 9, No. 1, March 1992, pp53-69.

28. Smith, P.G. and Reinertson, D.G. Shortening the Product Development Cycle. Research Technology Management, Vol. 35, No. 3, May-June 1992, pp44-49.

29. Cooper, R.G. Developing New Products On Time, In Time. Research Technology Management, Vol. 38, No. 5, September-October 1995, pp49-57.

30. Griffin, A. Evaluating QFD's Use in US Firms as a Process for Developing Products. Journal of Product Innovation Management,Vol. 9, No. 2, June 1992, pp171-187.

31. Swink, M.L., Sandvig, J.C. and Mabert, V.A. Customizing Concurrent Engineering Processes: Five Case Studies. Journal of Product Innovation Management, Vol. 13, No. 3, May 1996, pp229-244.

32. Blackburn, J.D., Hoedemaker, G. and Van Wassenhove, L.N. Concurrent Software Engineering: Prospects and Pitfalls. IEEE Trans. on Engineering Management, Vol. 43, No. 2, May 1996, pp179-188.

33. Handfield, R.B. Effects of Concurrent Engineering on Make-to-Order Products. IEEE Trans. on Engineering Management, Vol. 41, No. 4, November 1994, pp384393.

34. Hershock, R.J., Cowman, C.D. and Peters, D. Action Teams That Work. Journal of Product Innovation Management, Vol. 11, No. 2, March 1992, pp95-104.

35. Larson, E.W. and Gobeli, D.H. Organizing for Product Development Projects. Journal of Product Innovation Management, Vol. 5, No. 3, September 1988, pp180-190.

36. Mabert, V.A., Muth, J.F. and Schmenner, R.W. Collapsing New Product Development Times: Six Case Studies. Journal of Product Innovation Management, Vol. 9, No.3, September 1992, pp200-212.

37. Donovan, S.S. It's People Who Get New Products to Market Fast. Research Technology Management, Vol. 37, No. 5, September-October 1994, pp12-13.

38. Rosenau Jr., M.D. From Experience: Schedule Emphasis of New Product Development Personnel. Journal of Product Innovation Management, Vol. 6, No. 4, December 1989, pp282-288.

39. Cooper, R.G. The NewProd System: The Industry Experience. Journal of Product Innovation Management, Vol. 9, No. 2, June 1992, pp113-127.

40. Cooper, R.G. Third-Generation New Product Processes. Journal of Product Innovation Management, Vol. 11, No. 1, January 1994, pp3-14. 
41. Zirger, B.J. and Hartley, J.L. A Conceptual Model of Product Development Cycle Time. Journal of Engineering and Technology Management, Vol. 11, No. 3/4, 1994, pp229-251.

42. Nijssen, E.J., Arbouw, A.R.L. and Commandeur, H.R. Accelerating New Product Development: A Preliminary Empirical Test of a Hierarchy of Implementation. Journal of Product Innovation Management, Vol. 12, No. 2, March 1995, pp99109.

43. Griffin, A. Metrics for Measuring Product Development Cycle Time. Journal of Product Innovation Management, Vol. 10, No. 2, March 1993, pp112-125.

44. Griffin, A. The Effect of Project and Process Characteristics on Product Development Cycle Time. Journal of Marketing Research, Vol. XXXIV, No. 1, February 1997, pp24-35.

45. Page, A.L. Assessing New Product Development Practices and Performance: Establishing Crucial Norms. Journal of Product Innovation Management, Vol. 10, No. 4, September 1993, pp273-290.

46. Anonymous. High-Tech Companies Decrease Cycle Time. IIE Solutions, Vol. 28, No. 5, May 1996, p8.

47. New, C.C. and Szwejczewski, M. Performance Measurement and the Focused Factory: Empirical Evidence. International Journal of Operations \& Production Management, Vol. 15, No. 4, 1995, pp63-79.

48. Goffin, K., Szwejczewski, M. and New, C. Managing Suppliers: When Fewer Can Mean More. International Journal of Physical Distribution and Logistics Management, Vol. 27, No. 3, 1997, pp422-436. 
Table 1: Cycle Time - Performance by Sector for 340 Companies

\begin{tabular}{|c|c|c|c|c|}
\hline & Sector & $n$ & $\begin{array}{c}\text { Mean Cycle Time } \\
\text { (months) }\end{array}$ & Standard Deviation \\
\hline 1 & Interm. \& General Engineering & 148 & 16.0 & 10.7 \\
\hline 2 & Electronics & 63 & 16.8 & 10.5 \\
\hline 3 & Electronic Components & 33 & 14.0 & 8.3 \\
\hline 4 & Chemicals & 26 & 17.2 & 15.1 \\
\hline 5 & Food, Drink and Tobacco & 70 & 9.4 & 7.8 \\
\hline & Total & 340 & & \\
\hline
\end{tabular}


Table 2: Correlations between Complexity and Cycle Times for 335 Companies

\begin{tabular}{|l|c|c|c|}
\hline \multicolumn{1}{|c|}{ Sector } & $n$ & Correlation & $p$ \\
\hline 1. Interm. \& General engineering & 145 & .0739 & .377 \\
\hline 2. Electronics & 63 & .1618 & .205 \\
\hline 3. Electronic components & 33 & -.0155 & .932 \\
\hline 4. Chemicals & 26 & -.0646 & .754 \\
\hline 5. Food, drink and tobacco Total & $\underline{335}$ & .0609 & .622 \\
\hline \multicolumn{2}{r}{} & & \\
\hline
\end{tabular}


Table 3: Innovation Rate - Performance by Sector for 335 Companies

\begin{tabular}{|l|l|c|c|c|}
\hline \multicolumn{1}{|c|}{ Sector } & $n$ & $\begin{array}{c}\text { Median Innovation } \\
\text { Rate (\%) }\end{array}$ & $\begin{array}{c}\text { Top Quartile } \\
\text { Innovation Rate (\%) }\end{array}$ \\
\hline 1 & General engineering & 145 & 1.8 & 9.6 \\
\hline 2 & Electronics & 63 & 5.8 & 18.7 \\
\hline 3 & Electronic components & 33 & 7.5 & 17.7 \\
\hline 4 & Chemicals & 26 & 4.4 & 24.1 \\
\hline 5 & Food, drink and tobacco Total & $\underline{335}$ & 6.9 & 22.5 \\
\hline & \multicolumn{2}{r}{} & & \\
\hline
\end{tabular}

